Volume 11 Number 3, July-September 2017: pp. 302-316. Copyright (c) 2017 FIAT JUSTISIA. Faculty of Law, Lampung University, Bandarlampung, Lampung, Indonesia. ISSN: 1978-5186 | e-ISSN: 2477-6238.

Open Access: http://jurnal.fh.unila.ac.id/index.php/fiat

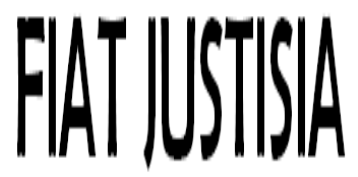

Fiat Justisia is licensed under a Creative Commons Attribution 4.0 International License, which permits unrestricted use, distribution, and reproduction in any medium, provided the original work is properly cited.

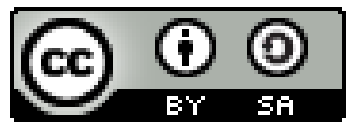

\title{
Legal Sanction of Kesepekang in Balinese Customary System (In Perspective: Empiricism Theory of David Hume)
}

\author{
I Ketut Seregig \\ Faculty of Law, University of Bandar Lampung \\ ketut1183@gmail.com
}

\begin{abstract}
Legal sanction of Kesepekang is a moral sanction that has been a habit in Balinese custom society and has been done from generation to generation, both the one in Bali and outside Balinese custom society. The implementation of Kesepekang sanction currently is considered by the intellectuals of Balinese custom society as a behavior that violates social values in society. In its development, legal sanction of Kesepekang has been politicized as a factor causing the occurrence of custom society disharmony, both the one in Bali and outside Bali. This society resistance has weakened the function of Balinese customary law sourced from one of Hinduism belief which is "believing the presence of karmaphala (result from behavior) law."

The issue occurring in Balinese custom society, especially the one in the Province of Lampung, is "whether the legal sanction of kesepekang is still relevant if it is applied in Balinese traditional system." Based on the observation result, the term of Kesepekang is the attitude of "silence" that is done by the other members of customers who do not obey the customary regulations in their groups. Certain groups consider that the legal sanction of Kesepekang has violated human nature as social beings. To prove this argument, a study entitled: Legal Sanction of Kesepekang in Balinese Customary System-(In Perspective: Empiricism Theory of David Hume) is conducted.

The result of the study can be concluded that the legal principles in Kesepekang sanction are the law of causation (causality), which each action certainly affects "when doing good, the result will be good - when doing bad, the result will be bad." In the perspective of David Hume's Empiricism
\end{abstract}


theory, Kesepekang sanction is a sensory experience that occurs in custom society. Experience, according to David Hume, is the only source of knowledge, so the act of "silence" done by the member of custom as the effort in giving punishment to the member of customer who does not obey is a reality received by sense as an experience.

\section{Keywords: Kesepekang Legal Sanction, Empiricism Truth Theory}

\section{A. Introduction}

Justice in law enforcement is an inevitability as long as there is an interest difference between individual and group in a social community in a country, in the same time justice will be a topic that is always interesting to be studied. Speaking about justice in general, there are 2 (two) systems that must be known; first, the justice that must be determined by the authority through state legal system is the justice that is determined by the judge in the judicial process, who is given the authority to give sanction of imprisonment and/or fine to the defendant on trial; second, the justice growing in a society through legal system in the society is the justice that is embodied by custom society based on regulation violation of a wig-a wig customs (custom regulation) that have been agreed by certain custom society, with the social sanction experienced by the violator, generally being not talked to, not given support when having celebration and others, basically following the actions violated by the member (customary krama), for example, if a member (customary krama) never helps other members, then, he/she will not be helped by other members.

In this journal, the one that will be studied is Kesepekang sanction that has developed in social life system of Balinese custom society, both the one in the Province of Bali and Lampung. According to Surpha, the legal sanctions that have been applied in Balinese Customary Law, are 3 (three) legal sanctions, which are; first, sanction of Jiwadanda (soul fine) done by apologizing to administrators or being temporarily suspended as a member of customary krama of village/Banjar for certain period; second, arthadanda (money fine) done by paying fine in accordance with the regulation determined in customary law; third, sangaskara danda done by holding ceremony of yadnya. ${ }^{1}$

In the perspective of Moch. Koesnoe, he conceptualized customary law in 2 (two) definitions, which are; first, customary law that is generally viewed, considers customary law as it is from the view of real action that is usually done by the social group in solving the problem of the society, that is basically similar to the habit, and it is in the real nature (empirical); second,

\footnotetext{
${ }^{1}$ I Wy. Surpha, Eksistensi Desa Adat di Bali, Denpasar Bali: Upada Sastra, (1993), p.22
} 
customary law in the perspective of experts who consider that customary law is abstract and normative that is the background of real action in physical experience nature. Custom or customary law is the value that lives, internalized, highly upheld, and conducted by citizens, and it is in the psychological nature as value, ambition, and the feeling of law that is normative, is the principle and rule on the social interaction according to the culture believed. According to the reflective morality, human only will be achieved perfectly, if the human as moral actor understands well the good and right action based on the freedom and self-devotion for moral ambition, as well as social development involving each member of the society. ${ }^{2}$

Artadi in the book entitled Law in the Perspective of Culture - Hukum Dalam perspective Kebudayaan, gave an interpretation on law and values based on the study on the aspect of law advantage in the life of customary Balinese society. According to him, based on the theory of western law, the law is divided into two sections which are criminal law and civil law. Criminal Law regulates the matter related to security, order, and serenity, while Civil Law regulates the problems related to the personal importance of society, to achieve certainty and fairness of the laws. Meanwhile, in civil law, the aim to be achieved is fair welfare, that is done by striving for conciliation before heading to the court trial. In Balinese society, the value of propriety is the main foundation in implementing Balinese customary law.

Legal certainty can be enforced if the act of society member violates the value of propriety. Besides the value of propriety, the principle of legal benefit is certainly the final goal that can be seen from whether the act is harming or defiling the name of the group. The principle of legal benefit is measured based on whether or not a prosperous life and common happiness are fulfilled. ${ }^{3}$ Besides the sanction of written law that is regulated in Balinese customary law, in the social life of Balinese custom society, the habits also grow and develop that are valued as moral sanction applied toward custom krama, which is; the legal sanction of Kesepekang that its implementation is by "being not talked to", and the worst is being excommunicated by custom krama. The result of the interview with Wayan Wirawan (Sekretaris Majelis Adat Pekraman Lampung Utara - Secretary of North Lampung Pekraman Custom Council) stated that in its practice in the society, the attitude and the action of "silence" shown toward customary regulation is as the effort of education toward custom krama who does not obey, but if he/she has realized his/her mistake by showing obedience to custom regulation, without

2 Gede AB. Wiranata. Hukum Adat Indonesia, perkembangannya dari masa kemasa, Bandung: Citra Aditya Bakti, (2005), p.141

${ }^{3}$ I Ketut Artadi. Hukum Dalam perspektif kebudayaan, pendekatan kebudayaan terhadap Hukum, Denpasar: Pustaka Bali Post, (2003), pp. 86-87 
being ordered, the custom krama will embrace the violator into his/her custom group.

Based on the observation in the society, this legal sanction of Kesepekang is still considered relevant to be applied because the value of fairness foundation in the legal sanction of Kesepekang is the result of the action. If an individual behaves well, the received result will be good, but if the individual is not able to behave well, the received result will not be good. The basic principles and justice in Kesepekang legal sanction is the reflection of a belief in Panca Sraddha (Five Sraddha), which is karma phala law. According to the information from Wayan Wirawan, legal sanction of Kesepekang is still run by the Balinese custom society in the District of North Lampung. The action of "nyepekang" has been a habit that is difficult to be eliminated from the Balinese custom system because it is related to the basic social values of society. This norm even has been the identity dan the culture of Bali that is based on salunglung sabayantaka principle meaning that sadness and happiness are shared; paras Paros sarpanaya meaning that deliberation is for consensus; asah-sasih-asuh meaning giving advice, caring each other, and guiding each other. These custom principles in Balinese custom system are still relevant to be applied in Balinese custom society. ${ }^{4}$

To avoid that a person does not receive Kesepekang sanction, what he/she must do is becoming those custom principles above, with the principle of cooperation, cooperation between an individual and other individuals. If customary norms that have been Balinese cultural behavior are violated by its member, the member of the custom will be imposed a sanction, such as; fine sanction in material, the sanction of conducting job, prayascitadesa (village purification). If this sanction has often been given, the last sanction will be given Kesepekang sanction that essentially is the form of justice value in Balinese Customary Law System. The interview result with Sumerthi, the head of Pekraman Custom of North Lampung, stated that if we want to receive service from other custom members, as a member, we must be obedient and obey the custom regulation, we must be diligent in helping customary jobs, such as; piodalan (ceremony), ngaben (cremation), and other ceremonies that need assistance from custom krama. The term of Kesepekang means to set aside or left alone if there is any job in the family the person is not assisted (not getting patus Karya), custom society even gives firmer sanction which does not allow to have ngaben (cremation) in the cemetery owned by the custom. If there is any policy of custom group administrators, it is certainly charged a cost named "penanjungbatu" meaning cremation cost. Regarding the amount of cost that must be spent by the violator, it is by the decision of custom meeting.

\footnotetext{
${ }^{4}$ I Ketut Seregig, Nilai Keadilan Hukum Adat Bali, Yogyakarta: Paradigma, (2010), p.75
} 
The result of observation done in the implementation of Kesepekang legal sanction in Lampung, Kesepekang legal sanction has been criticized by custom observers and Hinduism intellectuals because the implementation of this sanction is too much, for example, the existence of sanction that does not allow to use cemetery both for cremation and for burying custom members who passed away. According to the Head of Suma as Kelihan Banjar Tengah of Bandar Lampung, the sanction is considered not humane and not by the goal and purpose of the sanction giving to the custom member, even some moderate figures in Bali purposed that this sanction should be eliminated. Although the criticisms toward Kesepekang social sanction flow rapidly, in daily life interaction, these sanction values are still applied automatically. Why is it? Because these social sanctions are closely related to the attitude and the action of cooperation that has been the behavior of the culture in helping each other, hand in hand for the citizens of Indonesia, with the principle of "united we stand, divided we fall." If there is any custom member does not help others in the group, the member will not get any help from other members of custom in the group. According to Ketut Suma, it is the real meaning of Kesepekang legal sanction.

The sanction applied in Balinese custom system is unwritten habits that grow and develop in Balinese custom society (living law). This law is an experience applied from generation to generation, that becomes an unwritten law source. Based on the David Hume pure empiricism theory, it stated that pure empiricism is not an adequate foundation for science, but if one of these principles is recognized, other things can be continued by the theory that all of our sciences are based on experience. David Hume's theory is recorded in the college of philosophy stating that "empiricism is the source of all sciences that must be searched in experience."

The study on Legal System in Balinese Custom Village in Lampung is only a study sample, to give other perspectives, which there is a legal justice norm that grows and develops in the environment of Balinese custom society that is easily applied and obeyed by the judicial agency in state legal system. As well as law enforcement institution, it is difficult to fulfill the expectation of Balinese custom society that is very high to the law enforcer because the certainty and the fairness of law are not comparable in the law enforcement system in Indonesia.

To be able to investigate clearly, the problem of the study would be whether Kesepekang sanction is still developing and relevant to the situation and the condition of globalization occurring right now. As the answer to the problem above, a scientific study entitled "Legal Sanction of Kesepekang in

${ }^{5}$ Bertrand Russel, Sejarah Filsafat Barat, Yogyakarta: Pustaka Pelajar, (2004), p.881, Lorens Bagus, Kamus Filsafat, Jakarta: Gramedia Pustaka Utama, (2005) p.197 
Balinese Customary System" -(In Perspective: Empiricism Theory of David Hume) is conducted.

\section{B. Method}

This study is a qualitative study expressed in descriptive sentences that describe the scientific data collected by the researcher by using human as an instrument in the process of observation, interview, or document review, in order to get the empirical facts in the forms of texts, words, symbols, illustrations, among others are interview scripts, field records, photos, videotapes, personal documents, notes, or memos, and other official documents. Data collecting process uses law sociology approach that behavior of the member (krama) of Balinese custom in the implementation of Kesepekang legal sanction in Lampung through the approach of Balinese tradition and culture. ${ }^{6}$

Besides the interview, the researcher also conducted participant observation, by observing activities of people and listening to what they say as well as participating in their activities, it is in line with the perspective of Susan Stainback (1988) stating that "in participant observation the researcher observes what people do, listen to what they say, and participates in their activities".

In the setting of this analysis, the researcher does not conduct data testing specifically, but only studying the development symptom of object that is studied and conducting limited comparison with the existing theory, whether the condition of the object found has changed or not, whether Kesepekang legal sanction in Lampung culture is still running or not, and studying whether Kesepekang is still in accordance with the empiricism theory stated by David Hume, then the researcher will make a conclusion and data parameter of what must be searched; what information that must be proven; what question that must be answered, what method that must be eliminated to search new information and what error that must be fixed. ${ }^{7}$

Some arguments as the reference of this study among others are the arguments from Featherstone (1991), and Hannerz (1996) stating that globalization has brought a great power that needs a right response because it has forced a strategy to survive (survival strategy) and strategy to collect wealth (accumulative strategy). As well as the perspective of Appadurai (1994), it states that this process has brought "market" to be a dominant power in forming values and social order that focus on solid and sophisticated communication principles. The market has expanded the

\footnotetext{
${ }^{6}$ Kaelan, Metode Penelitian Kualitatif Bidang Filsafat, Yogyakarta: Paradigma, (2005), pp. 20-89

${ }^{7}$ Ibid., p. 214
} 
orientation of society and social-cultural limits and also has obscured socialcultural limits as the result of the change of spatial orientation in the society. ${ }^{8}$

\section{Discussion}

\section{Legal Sanction of Kesepekang}

The term Kesepekang means "set aside from daily interaction, being not talked to." In the practical ethics of custom interaction, the member of custom does not want to be labeled as not a good person. In the social life of Balinese custom, once being labeled "does not have a custom," then the statement will always be attached to the social life of the custom society. The effect of the negative statement that has been said is often difficult to be erased from the memory of other members of the custom. Wayan Wirawan in an interview stated that the factors causing a member (custom krama) of Balinese could be charged Kesepekang legal sanction, basically is related to the behaviour that contradicts with the regulation made and has been agreed together, for example: not attending the regular meeting for determined period in customary regulation without a justifiable reason. Rejecting customary decision, never paying custom patus (mandatory fee), rejecting when given task and responsibility from the Head of the custom, spreading hostility in the custom group and or other actions that can harm the harmony of life in Balinese custom village.

Actually the forms of behaviours above, in Hinduism ethics have been explained clearly, how the attitude and behaviour that must be done as the member (krama) of Balinese custom, in order to connect in harmony in the life of Balinese custom society, as custom society that upholds religious values so that each custom member has good and religious personality. In the village system of Balinese custom, the justice value becomes the basic necessity, it is mentioned in the principles of customary village, which are; salunglung sabayantaka (sadness and happiness are shared); paras-paros sarpanaya (equality principle); asah-asih-asuh principle (giving advice, caring, and guiding each other). Justice in positive law enforcement does not always fulfill the feeling of justice because on one side there is the one that is beneficial and the other side is disadvantageous. The understanding of the value of justice that is enforced by the court is different. Hinduism society views that material justice is pseudo because there are some disappointing people as the effect of justice enforced by the court. The value of justice fulfilling the feeling of justice of the society is the justice that can make

\footnotetext{
${ }^{8}$ Irwan Abdullah. Kontruksi dan Reproduksi Kebudayaan, Yogyakarta: Pustaka Pelajar, (2006), p.165
} 
them happy or can give satisfaction to both sides of litigation. It is certainly very difficult to be realized.

For the people of a customary Balinese village, the one that is fair is when an occurring case or dispute can be solved by deliberating and forgiving each other between two sides in litigation, to achieve the final goal which is to achieve happiness, free from the hostility. For them, the fairest law is karma phala law meaning that each action certainly has its result, if the action done is good, the result will also be good - but if people do not do a good action, the result will not be good. From the explanation, it can be understood that the judge or the court in decision making should consider the feeling of justice that is developing in the society because, however, the feeling of justice developing in the society will be much more effective than the feeling of justice that is created in the court. Regarding the implementation of karma phala law, it creates Kesepekang sanction applied in Balinese customary village. Kesepekang sanction applies if a person in certain customary village group behaves badly, apathetic toward his/her custom group, and does not want to help other members, the member of the custom group will be set aside from the interaction of custom that is known as Kesepekang.

\section{The system of Customary Institution}

Customary village system conducted in Bali is a system of legal society that has been rooted from generation to generation as the heritage of the ancestors, so wherever they are, the customary village system will be running in daily life, by running the system of customary village, they consider that they have conducted religious teachings because all religious activities written on panca yadnya are run in customary Balinese system. Therefore, in the life of customary Balinese society, social, ethical principles that become the view of life in interaction are; satiawacana that means faithful with what they say; polos that mean frankly; lekkaucapJele that means ashamed to be labeled not good; jengah that means motivation to do maximally; sagilik-saguluk that means united as a whole; salunglung sabayantaka that means difficult to be done together; paras-paros that means tolerance; ngandapkasor that means down to earth; nindihin patut that means to defend the truth; puputan that means to keep the truth completely; urunan that means mandatory fee for common needs; menyame-braye that means to seek family; pang pade payu that means to be fair to others.

The implementation of Kesepekang legal sanction in Lampung has not been fully run because normatively Balinese customary law does not regulate firmly, whether it applies to Balinese society only in Bali or outside Bali. As well as in its writing, the norms of Balinese customary law are not arranged clearly by the rules of customary regulations writing that they 
inherited in Bali. In the traditional organization system of Balinese custom, there are two forms of village organizations that substantially and functionally have different duty and responsibility, which are the customary village and the official village. Both organizations have different characteristics and attachment of society member toward the organization. A customary village is a unit of an area where its citizens together do religious activities to maintain the holiness of the village. The attachment of custom member toward the organization occurs because there is a territorial area of the village, awig-awig of the customary village (customary village regulations) and kahyangantiga (third kahyangan) as the place of worship for God.

Meanwhile, the official village is a unit of the administrative area under a district, so it is a part of a vertical structure from the government. The society of the official village has the function to maintain and to activate the activities in the village and to obey the applied regulation system. ${ }^{9}$

The definition of village as written in Article 1 point 1 of Law Number 6 Year 2016, states that "Village and Customary Village or the one that is named with other names, then it is named as a village which is a unit of legal society that has an area of borderline that is responsible for managing the government affairs, the importance of local society based on the community initiatives, rights of origin, and/or traditional rights that are recognized and respected in the government system of the Republic of Indonesia". With the existence of the village law, it clarifies more the position, the function, and the role of customary village including Balinese Customary Village that is not only in Bali, but also outside Bali, because it has the rights of origin and traditional rights as a traditional organization between other organizations that have Hinduism nuance inherited from the ancestors to the next generations. The system of the customary village has been implemented from generation to generation, which eventually became the social system that has the principles of togetherness, cooperation, hand in hand in conducting customary activities and PancaYadnya.

The strong connection in the system of customary Balinese village becomes the base of behavior for customary Balinese society wherever they are. Through this system, customary Balinese society in the Province of Lampung still conducts the system of customary Balinese village, and the existence of this customary system is respected well by the local society. It makes them feel at home when living far away from where they were born or homeland (Tanah Kawitan) which is Bali. Although living far away from their Tanah Kawitan (where they were born), they still love their ancestors

\footnotetext{
${ }^{9}$ I Gusti Ngurah Gorda, Etika Hindu dan Perilaku Organisasi, Singaraja Bali: STIE Satya Dharma, (2006), p.187
} 
and homeland in Bali. This bond cannot be denied, especially the ones who claim as a Balinese and Hindu. In the life of Balinese customary village system, there are 3 (three) groups of kinship line. The base of relation that is very specific in kinship system in Balinese custom is the occurrence of brotherhood social relation based on male lineage (purusa). The effect of the clan on its members is very substantial, although they live in other places (overseas), they are still bound to religious obligations together which are conducting ceremonies. The development the clan as the base of social life in Balinese customary society is increasing each year, then in system kinship of customary Balinese village enables the possibility of a new group to be established, but it still refers to the male lineage. ${ }^{10}$

The interview result with some administrators of the custom is the empirical fact proving that legal sanction of Kesepekang is still conducted in Balinese Customary System. The third statement of the administrator of Majelis Adat Pekraman (Pekraman Customary Forum), that is strengthened by the statement from Made Pasti as the Head of Majelis Adat Pekraman Lampung Selatan (Forum of Lampung Selatan Pekraman Custom) stating how is it possible for a member of custom who is lazy, or never attends in the cooperating activities, or never spends the mandatory fee for the deaths, so he/she will be helped by other members? In customary Balinese system, it is impossible to happen. Based on the explanation above, a clear illustration on how Balinese people are very bound with their ancestor land is obtained. Beside the clan bound that binds the society of Balinese custom in the form of brotherhood. It is the source of behavior ethics of Balinese in the daily social life wherever they are. Besides the existence of the belief, customary Balinese society upholds the advice from the ancestors that is believed to have a great effect in pursuing success in the life of the individuals from their heredity. In improving manners, ethics, morality, unity, brotherhood, harmony, and peace in living in the world, Bhisama is delivered from the ancestors as follows

\section{Bhisama Ida Betara Kawitan (Ancestor Advice)}

You are Pasek and Bendesa, do not forget of your kahyangan sesembahan, such as the one in Mount Lempuyang, in Besakih, in Silayukti (Padang Bai) along with the one in Gelgel of Dasar Buana. If you forget it, I wish you are not getting well, unstoppable difficulty, never-ending contention, having many job skills, but less income. It is my words to you as well as my descendant (my generation), that have been written on the inscription that you follow together. You cannot resist my order; it is very dangerous, do not even forget it. If you accept and obey my order, I wish

${ }^{10}$ Ibid., p. 186 
you a long life, to enjoy noble dignity, to have meaningful skills; each word said will be a reality, to be respected in this world, loved by God, because you are wise, polite, and good in problem-solving. ${ }^{11}$

Regarding the moral messages in the petuah leluhur (ancestor's advice) above, it contains very high ethical values, the concept of bhakti (devotion) that must be conducted by all descendants is very noble and the wisest. Petuah (advice) is the holy order containing norms as the guide for their descendants to live as a noble human being, always to be role model for others and the most important thing in the bhisama above is the obligation to worship their stana (palace). Thus, if the holy order is not done, the descendants will be miserable and lost into a ravine of destruction far from happiness, always quarrel and never get along well with the family members.

The meaning in the petuah (advice) above is the awakening of social characteristics and brotherhood that are tight and eternal, not only in one clan but also toward other relatives including the relatives because of the relation of marriage. In this bhisama, it is expected that its generations not to be exclusive, excessive fanaticism, but they are expected to be customary Balinese society that is religious and have moral. It is the highest meaning of values in bhisama of Ida Betara Kawitan. He does not want his descendants to behave improperly in searching for living and dishonest in words. However, on the contrary, they always follow the characteristics of the essential kepanditaan and prevent themselves from a-dharma actions.

The interview result with some prajuru (custom administrators) above, it is the evidence that there are empirical facts that Kesepekang legal sanction is still done in Balinese Customary System. The statements of the three administrators of Pekraman Custom Forum are supported by the statement of Made Pasti as the Head of Pekraman Custom Forum of Lampung Selatan District, stating that how it is possible for a member of custom who is lazy or never attends in cooperation activities, or does not want to pay mandatory fee for the death, he/she will be helped by other customary members. In customary Balinese system, it is impossible to occur.

\section{Empiricism Theory of David Hume}

Empiricism is from Greek-empeiria, empeiros (experience in, introducing to, able to), and in Latin-experiential (experience). Thus, the definition of empiricism is a doctrine that the source of all sciences must be searched in an experience. Empiricism philosophers assumed that sense is the only source of science, at least the primary.

\footnotetext{
${ }^{11}$ Pasek Suardika, Bhisama Pasek. Denpasar Bali: Aga Denpasar, (2006), pp.17-18
} 
The perspective on empiricism is that the special issue of this philosophy is explaining the concept and universal decision only through experience. It is no doubt that "we start all sciences through experience" and is particularly conditioned by experience, even the statement "all sciences are based on experience is true." ${ }^{12}$ Empiricism was initially introduced by Francis Bacon (1561-1626) stating that a course from modern philosophy is the one conducting rejection of metaphysics philosophy. Empiricism philosophy is claimed as the most trusted truth. Then, after the era of Thomas Hobbes (1588-1679), John Locke (1632-1704), and George Berkeley (1685-1753), empiricism reached its peak in the era of David Hume who is considered as the first thinker of positivism because he denied everything that exceeds pure facility. In his theory, David Hume denied the assumption of rationalism stating that there are ideologies and principles we have known from the mind separated from all experiences. According to Hume, the content of consciousness is from the sensory experience. Hume rejected the existence of truths that are absolute and certain. All truths are factual, meaning that they are based on the existence of sensory impression or data of accidental experience. ${ }^{13}$

The interesting matter in this empiricism theory is the push to attempt what is useful so that we feel satisfied, also to make others feel satisfied and to protect them from pain. Thus, we also are motivated to behave well - we feel the kindness. It is the main feature of Hume hedonism that is unique and not selfish. Justice from the perspective of Hume is "artificial quality." Artificial means that justice is not natural, but it develops in the end when humanity is facing the social problem. With the justice that is meant the protection toward the rights of each of us and for public welfare, those rights need to be guaranteed, so they cannot be violated. If they are violated, there will be chaos. ${ }^{14}$

The effect of David Hume empiricism theory is rapidly known throughout Europe until now it has greatly affected the human system of life. The effect of Hume empiricism theory is that empiricism will be the identity of most modern science including philosophy, and Hume is the figure as the reference of modern empiricism. Empiricism theory concludes that Hume formulated some philosophical principles sharply that became the pillar of modern philosophical schools. For example, utilitarianism school gets stimulation from Hume ethics because of Hume who formulated human "obligation" toward others as utilitaristic, as the inclination to attempt the formulation of Hutcheson, which is; the greatest happiness for

\footnotetext{
${ }^{12}$ Lorens Bagus, Kamus Filsafat, Jakarta: Gramedia Pustaka Utama, (2005). pp.197-200

${ }^{13}$ Frans Magnis Suseno, 13 TokohEtikaSejakJamanYunani Sampai Abad ke-19, Yogyakarta:Kanisius, (1997), pp. 123-124

${ }^{14}$ Ibid., p. 127
} 
the greatest number, morality becomes the calculation of balance between pleasant and unpleasant feelings. ${ }^{15}$

In the history of Western philosophy, to investigate pure or whole empiricism, it needs to study traditions that give bigger pressure to the observation compared to the idea or the essence. The Greek philosophers named Demokritos and Epikurus returned knowledge to an influx or (wave) shadow or (image) from everything that is perceived, and all knowledge to material residual. Then, in the middle age, William Ockham created a distinction between two types of knowledge. First is evident knowledge of the meanings of terms. Second is evident knowledge based on the experience. ${ }^{16}$

To prove the pure empiricism theory from David Hume stating that all the knowledge we have is from experience, Hume delivered the final result of the investigation conducted by him that introduced experimental reasoning method about a moral subject. It is clear that he started with the belief that what is produced by the scientific method is the whole truth, but he ended with the stance that the belief is never rational because we never know everything. After making skepticism argument, he did not deny the argument but return to his natural habit, which is the tendency to believe quickly. ${ }^{17}$ The record of David Hume (Book I, Sectioiv, Subsection i) in his book entitled "Treatise" about skepticism is as follows:

"Nature, absolutely and inevitably, has determined us to value as we breathe and feel. We also cannot wait to be able to see certain objects more brightly and clearly - with the note that those objects are related to the present impression - compared to our effort to avoid ourselves from thinking as long as we are awake, or to see various bodies around us when we direct our perspective to object during the day. Whoever insists on refusing this total skepticism, he/she will reject it without fighting it and creates an argument to determine a characteristic that has been previously implanted in mind, to turn it to be inevitable. My goal in explaining the argument accurately about the fantasy course is only to make the reader understand the truth of my hypothesis that all of our reasons for cause and effect none other are from our habits; and that belief will be more precise if it is called the action of sense, compared to the action of understanding that is part of our nature".

Based on the above explanation, it can be understood that the perspective of David Hume that the source of knowledge only can be searched inexperience and its truth is no doubt. We know that thing exists, based on our knowledge of sensing done previously. In Kesepekang legal

\footnotetext{
${ }^{15}$ Ibid., p. 129

${ }^{16}$ Ibid., p. 198

${ }^{17}$ Bertrand Russel, Sejarah Filsafat Barat, Yogyakarta: Pustaka Pelajar, (2004), p.877
} 
sanction, empiricism is interpreted as experience about the habit that grows and develops as normative law in Balinese customary society that must be obeyed because the goal to be achieved is the harmony in the social life of customary Balinese society wherever they are.

\section{Legal Sanction of Kesepekang in the Perspective of David Hume Empiricism Theory:}

If Kesepekang legal sanction is studied in the perspective of David Hume with Empiricism theory, it seems clear that there is firm correlation between Empiricism theory and Kesepekang sanction, that Kesepekang legal sanction is a habit, that is agreed in Hume Empiricism, that there is a push to attempt what is useful so that we feel satisfied and also to make others feel satisfied and to protect self from pain. In skepticism, eventually, David Hume gave special note so that the reader understands that "all of our reasons for cause and effect that none other is from habit." Meanwhile, legal sanction of kesepekang starts from a habit that is determined as an unwritten law in customary Balinese system. In the sanction, there are the values that aim to educate the member of custom to be aware of their mistakes and to conduct the obligation regulated in customary regulation again.

The implementation of kesepekang legal sanction aims for happiness and harmony in the life of custom group because the norm cannot be violated because if it is violated, the expected benefit in Balinese customary system that has been agreed cannot be achieved. In its practice, Kesepekang legal sanction only sees behaviour that can be observed factually and it is an experience that has grown and developed since the existence of the custom group, whether the behaviour done by custom member (krama) can bring happiness for others or not, besides the benefit, whether he/she also can or cannot enjoy the effect of the attitude and the behavior performed in the custom group, where he/she is one of the members (krama) of the customary system.

\section{Conclusion}

Based on the result of this study, legal sanction of Kesepekang in the perspective of David Hume's theory can be concluded as follows:

1. Kesepekang legal sanction is a habit that grows and develops in customary Balinese society (living law) aiming to change the behavioral attitude of custom members who are lazy and disobedient toward the customary regulation to be diligent and obedient toward the customary regulation.

2. Kesepekang legal sanction is not a negative social behavior culture, but an effort to build an attitude so that the member (krama) of the custom is encouraged to conduct good deeds, so they can enjoy the 
result and the enjoyment also must be enjoyed by others to protect the member (krama) of the custom from the pain.

3. the implementation of Kesepekang legal sanction for Balinese custom society in Lampung Province indirectly applies in the custom of daily interaction. If a person never helps others in the group, he/she will never be helped sincerely by his/her custom group. These facts have been applied in the living interaction system of Balinese custom society in the Province of Lampung.

\section{A. Book}

\section{Bibliography}

Abdullah, Irwan. (2006). Kontruksi dan Reproduksi Kebudayaan. Yogyakarta: Pustaka Pelajar.

Artadi, I Ketut. (2006). Hukum Dalam Perspektif kebudayaan, pendekatan kebudayaan terhadap Hukum. Pustaka Bali Post.

Bagus, Lorens. (2005). Kamus Filsafat. Jakarta: Gramedia Pustaka Utama.

Gorda, I Gusti Ngurah. (2006). Etika__Hindu dan Perilaku Organisasi. Singaraja: STIE Satya Dharma.

Kaelan. (2005). Metode Penelitian Kualitatif Bidang Filsafat. Yogyakarta: Paradigma.

Russel, Bertrand. (2004). Sejarah FilsafatBarat. Yogyakarta: Pustaka Pelajar.

Seregig, I Ketut. (2010). Nilai Keadilan Hukum Adat Bali. Yogyakarta: Paradiga.

Pasek, Suardika. (2006). Bhisama Pasek. Denpasar: Bali Aga.

Surpha, I Wayan, Eksistensi Desa Adat di Bali. Denpasar Bali: Upada Sastra. Suseno Magnis, Franz. (1997), 13 Tokoh Etika Sejak Jaman Yunani Sampai Abad ke-19. Yogyakarta: penerbit Kanisius.

Wiranata AB, I Gede. (2005). Hukum Adat Indonesia, perkembangannya dari masa kemasa. Bandung Citra Aditya Bakti.

\section{B. Direct Interview}

Kelian Adat Pekraman Banjar Tengah Bandar Lampung, I Ketut Suma represents the member of custom in the city of Bandar Lampung.

Ketua Majelis Adat Pekraman Lampung Utara, Ni Nyoman Sumerthi, S.Pd., MPd. is in Kotabumi, Lampung Utara.

Secretary of Majelis Adat Pekraman Lampung Utara, Wayan Wirawan, is in Sungkai Selatan Kabupaten Lampung Utara. 